\title{
PENERAPAN PENDEKATAN OPEN ENDED DALAM PEMBELAJARAN MATEMATIKA UNTUK MENINGKATKAN HASIL BELAJAR SISWA SMP NEGERI 9 KOTA BIMA
}

\author{
Nur Baeti* \\ Sekolah Tinggi Keguruan dan Ilmu Pendidikan (STKIP) Bima \\ *Email korespondensi: nurbaeti_betty7@yahoo.com
}

\begin{abstract}
ABSTRAK
Penelitian ini bertujuan untuk meningkatkan hasil belajar siswa dalam pembelajaran matematika dengan pendekatan Open Ended. Penelitian ini merupakan Penelitian Tindakan Kelas (Classroom Action Research) yang terdiri atas dua siklus, dimana tiap siklus terdiri dari empat tahapan yaitu perencanaan, pelaksanaan tindakan, observasi, evaluasi, dan refleksi. Subjek penelitian ini adalah siswa SMP Negeri 9 Kota Bima. Analisis data dilakukan secara kuantitatif dan kualitatif. Analisis kuantitatif dilakukan dengan menggunakan data hasil belajar siswa. Analisi kualitatif dilakukan dengan menggunakan data hasil lembar observasi pada saat proses belajar mengajar. Dari hasil pengolahan data diperoleh persentase ketuntasan belajar pada siklus I adalah 76,4 \% dengan nilai rata-rata 75,18, sedangkan persentase ketuntasan belajar pada siklus II adalah 90\% dengan nilai rata-rata 83,26. Perolehan rata-rata skor aktiviitas belajar siswa siklus I dan II sebesar 3,49 dan 3,87 dengan kategori aktif. Hasil penelitian menunjukan bahwa siswa lebih aktif dalam proses belajar mengajar serta terjadi peningkatan hasil belajar siswa pada tiap siklus dengan menggunakan pendekatan Open Ended.
\end{abstract}

Kata kunci: open ended, pembelajaran matematika, hasil belajar.

\begin{abstract}
This study aims to improve student activity and learning outcomes in mathematics learning with the Open Ended approach. This research is a Classroom Action Research which consists of two cycles, where each cycle consists of four stages, namely planning, implementing the action, observing, evaluating, and reflecting. The subjects of this study were student of class of student of Bima City Middle School 9. Data analysis was carried out quantitatively and qualitatively. Quantitative analysis was carried out using data on student learning outcomes. Quantitative analysis was carried out using data from the observation sheet during the teaching and learning process. From the result of data processing, the percentage of learning completeness in the first cycle was $76,4 \%$ with an average value of 75,18 , while the percentage of learning completeness in the second cycle was $90 \%$ with an average value of 83,26 . The average score of student activity in cycle I and II was 3,49 and 3,87 in the active category. The result showed that student were more active in the teaching and learning process and there was an increase in student learning outcomes in each cycle using an Open Ended approach.
\end{abstract}

Keywords: open ended, mathematics learning, learning outcomes. 


\section{PENDAHULUAN}

Matematika merupakan human activity karena pembelajaran matematika bertujuan untuk mengembangkan aktivitas kreatif yang melibatkan imajinasi, intuisi dan penemuan dengan mengembangkan pemikiran divergen, orisinil, rasa ingin tau, membuat prediksi dan dugaan serta mencoba-coba (Karina dalam Fitriani, 2015). Mengembangkan kemampuan berpikir logis, analitis, sistematis, kritis dan kreatif, serta kemampuan bekerjasama sudah lama menjadi fokus dari pendidik matematika di kelas, karena hal itu berkaitan dengan sifat dan karakteristik keilmuan matematika. Lebih lanjut Mulyadin (2019) mengungkapkan bahwa sebagai salah satu sumber ilmu, peran guru dalam merancang pembelajaran yang menarik, mudah diterima siswa, dan pembelajaran yang berhubungan dengan kehidupan sehari-hari siswa merupakan salah satu kunci dalam proses pembelajaran matematika yang lebih bermakna. Hal ini menjadikan bahwa berhasil tidaknya suatu proses kegiatan pembelajaran bergantung pada kemampuan kreativitas guru menciptakan proses belajar yang sedemikian rupa sehingga dapat merangsang siswa untuk belajar secara aktif (Slameto dalam Sowanto, 2010).

Dalam proses belajar ada beberapa faktor yang mempengaruhinya yaitu faktor internal, eksternal, dan pendekatan belajar. Penting bagi seorang guru untuk memperhatikan faktorfaktor yang mempengaruhi belajar karena hal ini dapat mempengaruhi hasil belajar siswa. Sebuah proses pembelajaran dikatakan berhasil jika mencetak hasil belajar yang baik, hasil belajar yang baik diperoleh bukan hanya dari peserta itu sendiri melainkan juga dari pihak guru yang mengajar. Seorang guru harus dapat membangkitkan minat belajar siswa, karena jika seseorang senang pada suatu hal maka orang tersebut akan melakukannya dengan perasaan senang dan melakukan berbagai usaha agar dapat mencapai apa yang ia inginkan. Hal tersebut juga berlaku pada minat belajar peserta didik, jika seorang peserta didik memiliki minat yang tinggi terhadap pelajaran tertentu berarti siswa tersebut menyukai pelajaran tersebut, merasa senang ketika proses pembelajaran berlangsung, dan akan berusaha mendapatkan hasil belajar yang maksimal dengan belajar.

Pembelajaran yang baik sebaiknya dilakukan dengan model student center yaitu pembelajaran yang melibatkan siswa secara aktif dalam proses pembelajaran di kelas sehingga siswa akan lebih tereksplorasi dan di sini guru hanya berfungsi sebagai media fasilitator saja. Pada kenyataannya tidak semua guru menerapkan hal ini di kelas, masih banyak ditemukan 
guru yang menggunakan model teacher center dalam proses pembelajaran. Model pembelajaran teacher center adalah pembelajaran yang didominasi oleh guru dan tidak melibatkan siswa dalam pembelajaran di kelas, di sini biasanya guru hanya mengandalkan ceramah di depan kelas kemudian siswa hanya mendengarkan tanpa memberikan kesempatan siswa untuk bertanya dan berpendapat terkait dengan materi pelajaran. Hal tersebut membuat siswa kurang terekplorasi lagi dan dapat berdampak pada hasil belajar siswa yang kurang baik.

Hasil observasi dan wawancara dengan guru bidang studi matematika SMP Negeri 9 Kota Bima diperoleh informasi terdapat permasalahan dalam pembelajaran. Permasalahan tersebut diantaranya rendahnya aktivitas siswa dalam pembelajaran. Hal ini terlihat dari jarangnya siswa bertanya dan mengeluarkan pendapat dan ide-ide pada saat pembelajaran berlangsung. Hal ini terjadi karena selama ini dalam menyampaikan materi pelajaran guru banyak menerapkan metode ceramah sehingga siswa hanya mendengar, mencatat dan mengerjakan soal yang diberikan sehingga interaksi peserta dengan guru cenderung pasif.

Hal ini menuntut perubahan-perubahan dalam pengorganisasian kelas, penggunaaan metode mengajar, strategi belajar-mengajar, maupun sikap dan karakteristik guru dalam mengelola proses belajar mengajar, bertindak selaku administrator yang berusaha menciptakan kondisi belajar yang efektif sehingga memungkinkan proses belajar-mengajar, mengembangkan bahan pelajaran denganbaik, dan meningkatkan kemampuan siswa untuk menyimak pelajaran yang menguasai tujuan-tujuan pendidikan yang harus mereka capai. Sehingga guru dituntut mampu mengelola proses belajar mengajar yang memberikan rangsangan kepada siswa sehingga ia mau belajar karena siswa subjek utama dalam belajar. Dalam menciptakan kondisi belajar-mengajar yang efektif harus ada partisipasi aktif dari siswa, apalagi dalam pembelajaran matematika.

Menurut Djamarah (2002) dalam belajar, seseorang tidak akan dapat menghindarkan diri dalam suatu situasi. Situasi akan menentukan aktivitas apa yang akan di lakukan dalam rangka belajar. Bahkan situasi itulah yang mempengaruhi dan menentukan aktivitas belajar apa yang dilakukan kemudian. Setiap situasi dimanapun dan kapanpun memberikan kesempatan belajar kepada seseorang. Adapun aktivitas belajar, yaitu a) mendengarkan; b) memandang; c) menulis/mencatat; d) membaca; e) mengamati tabel-tabel;diagram-diagram dan bagan-bagan; f) mengingat; g) berpikir. 
Pembelajaran pada hakikatnya merupakan suatu proses interaksi antara guru dengan siswa, baik interaksi secara langsung seperti kegiatan tatap muka maupun secara tidak langsung, yaitu dengan menggunakan berbagai media pembelajaran. Didasari oleh adanya perbedaan interaksi tersebut, maka kegiatan pembelajaran dapat dilakukan dengan menggunakan berbagai pola pembelajaran (Rusman, 2012). Guru sebagai orang yang memegang peranan penting dalam pembelajaran, diharapkan mampu menciptakan kondisi belajar yang dapat melibatkan siswa secara aktif melalui pendekatan Open Ended.

Pendekatan Open Ended sebagai salah satu pendekatan dalam pembelajaran merupakan suatu pendekatan yang memungkinkan siswa untuk mengembangkan pola pikirnya sesuai dengan minat dan kemampuan masing-masing. Hal ini disebabkan karena, pada pendekatan Open Ended formulasi masalah yang digunakan adalah masalah terbuka. Masalah terbuka adalah masalah yang diformulasikan memiliki multi jawaban (banyak penyelesaian) yang benar. Di samping itu, melalui pendekatan Open Ended, siswa dapat menemukan sesuatu yang baru dalam penyelesaian suatu masalah, khususnya masalah yang berkaitan dengan matematika. Dengan dasar ini, maka pendekatan Open Ended dapat diterapkan dalam proses pembelajaran dalam kelas di sekolah (Rismayanti, 2014). Hal ini juga diperkuat dengan hasil penelitian dari Mikrayanti (2019) yang menyatakan bahwa pendekatan Open Ended dapat meningkatkan hasil belajar siswa, hal ini salah satunya ditunjang karena pendekatan Open Ended membantu mengembangkan kegiatan kreatif dan pola pikir matematis siswa melalui problem solving secara simultan.

Dalam pembelajaran dengan pendekatan Open Ended, siswa diharapkan bukan hanya mendapatkan jawaban tetapi lebih menekankan pada proses pencarian suatu jawaban. Siswa yang dihadapkan dengan Open Ended, tujuan utamanya bukan untuk mendapatkan jawaban tetapi lebih menekankan pada cara bagaimana sampai pada suatu jawaban. Sifat "keterbukaan" dari suatu masalah dikatakan hilang apabila hanya ada satu cara dalam menjawab permasalahan yang diberikan atau hanya ada satu cara dalam menjawab permasalahan yang diberikan atau hanya ada jawaban yang mungkin untuk masalah tersebut.Berdasarkan uraian di atas, penelititertarik untuk meneliti penerapan pendekatan Open Endeddalam pembelajaran matematika yang diharapkan dapat meningkatkan aktivitas dan hasil belajar siswa kelas VII SMP Negeri 9 Kota Bima. 


\section{METODE PENELITIAN}

Penelitian ini merupakan Penelitian Tindakan Kelas (PTK) yang dilaksanakan dalam dua siklus. Pelakasanaan penelitian dimulai dengan siklus pertama yang terdiri dari empat tahapan menurut Kemmis dan Mc Taggart (dalam Wijaya K dan Dedi D, 2010) yaitu Perencanaan, Pelaksanaan, Observasi, dan Refleksi. Perencanaan dalam penelitian ini berupa penyusunan rancangan tindakan yaitu dengan menyusun Rencana Pelaksanaan Pembelajaran (RPP) dengan model pendekatan Open Ended pada tiap pertemuan, membuat Lembar Kerja Siswa (LKS), membuat instrumen penelitian dan pedoman penskoran tiap siklus. Pelaksanaan dalam penelitian ini adalah implementasi tindakan dalam kegiatan pembelajaran. Observasi yaitu mengamati dan mencatat hal-hal penting yang terjadi selama pelaksanaan tindakan berlangsung. Refleksi adalah mengkaji secara keseluruhan proses pembelajaran atau tindakan yang dilakukan dan dilanjutkan dengan evaluasi guna menyempurnakan tindakan berikutnya. Siklus kedua merupakan kegiatan yang sama dengan kegiatan pada siklus pertama.

Dalam penelitian ini yang menjadi subyek penelitian adalah siswa kelas VII SMP Negeri 9 Kota Bima yang berjumlah 40 orang dengan tingkat kemampuan heterogen. Dimana peneliti sebagai pengajar dan guru sebagai observer. Metode pengumpulan data dalam penelitian ini diperoleh melalui observasi aktivitas siswa dan guru, dan tes. Menganalisis tingkat keberhasilan atau persentase keberhasilansiswa setelah proses belajar mengajar setiap siklusnya dilakukan dengan cara memberikan evaluasi berupa soal tes tertulis pada setiap akhir siklus. Analisis data dilakukan secara kuantitatif dan kualitatif. Analisis kuantitatif dilakuan dengan mencari ketuntasan belajar siswa yang terdiri dari ketuntasan klasikal terhadap hasil belajar matematika siswa setelah penerapan pendekatan Open Ended di kelas. Analisi kualitatif untuk menelaah aktivitas siswa dan guru selama proses pembelajaran berlangsung. 


\section{HASIL DAN PEMBAHASAN}

Hasil penelitian menunjukkan terjadi peningkatan rata-rata skor aktivitas dan hasil belajar siswa pada siklus I dan siklus II yang dapat dilihat pada tabel berikut.

Tabel 1. Hasil Observasi Aktivitas dan Hasil Evaluasi Belajar Siswa dalam Dua Siklus

\begin{tabular}{ccccccc}
\hline & \multicolumn{2}{c}{$\begin{array}{c}\text { Aktivitas Belajar } \\
\text { Siswa }\end{array}$} & \multicolumn{2}{c}{ Prestasi Belajar Siswa } & \multirow{2}{*}{$\begin{array}{c}\text { Ketuntasan } \\
\text { Siklus }\end{array}$} \\
\cline { 2 - 6 } & $\begin{array}{c}\text { Rata-rata } \\
\text { Skor }\end{array}$ & Kategori & $\begin{array}{c}\text { Nilai } \\
\text { Terendah }\end{array}$ & $\begin{array}{c}\text { Nilai } \\
\text { Tertinggi }\end{array}$ & $\begin{array}{c}\text { Nilai } \\
\text { Rata-rata }\end{array}$ & \\
\hline I & 3,49 & Aktif & 45 & 100 & 75,18 & $76,4 \%$ \\
II & 3,87 & Aktif & 50 & 100 & 83,26 & $90 \%$ \\
\hline
\end{tabular}

Berdasarkan data pada tabel 1 di atas,skor aktivitas siswa pada siklus I adalah 3,49 yang berkategoriaktif dan analisa data hasil belajar siswa pada siklus I diperoleh nilai rata-rata siswa adalah 75,18 dan persentase ketuntasan belajar siswa adalah76,4\%. Hasil evaluasi siklus I menunjukkan bahwa ketuntasan secara klasikal belum memenuhi kriteria keberhasilan, ini disebabkan karena pada siklus I belum maksimal penerapan pendekatan Open Ended ini terlihat dari siswa yang masih kurang memahami materi yang diajarkan oleh guru dan dan pada saat diskusi masih ada siswa yang tidak menanggapi dengan baik penjelasan temannya sehingga perlu dilakukan tahap refleksi pada siklus II. Setelah dilakukan perbaikan, terlihat pada siklus II hasil evaluasi mengalami peningkatan. Hal ini tampak dari keaktifan siswa yang meningkat dengan rata-rata skor sebesar 3,87 yang berkategori aktif dan analisa data hasil belajar siswa pada siklus IImengalami peningkatan dengan nilai rata-rata siswa adalah 83,26 dan persentase ketuntasan belajar siswa adalah 90\%. Karena target yang ditetapkan telah terpenuhi, dapat dipastikan tidak perlu ditindaklanjuti dalam siklus selanjutnya.

Peningkatanhasilbelajarsiswajugadidukungolehadanyapeningkatanaktivitassiswasaatke giatanbelajarmengajar.Sehingga dapat dismpulkan Penerapan pendekatan Open Ended yang digunakan dapat meningkatkan kemampuan berpikir siswa. Hal ini sejalan dengan pendapat Suherman dkk (2011) bahwa pokok pikiran pembelajaran dengan pendekatan Open Ended yaitu pembelajaran yang membangun kegiatan pembelajaran yang interaktif antara matematika dengan siswa sehingga mengundang siswa untuk menjawab permasalahan dengan berbagai strategi. Sehingga dapat disimpulkan bahwa penerapanpendekatan Open Ended dapat meningkatkan hasil belajar siswa kelas VII SMP Negeri 9 Kota Bima. 


\section{KESIMPULAN}

Berdasarkan hasil penelitian yang diperoleh melalui penelitian terhadap peningkatan aktivitas dan hasil belajar siswa dalam penerapan pendekatan Open Ended pada pembelajaran matematika di kelas VII SMP Negeri 9 Kota Bima dapat disimpulkan yaitu; 1) pendekatan Open Ended memberikan kontribusi pada peningkatan aktivitas pembelajaran matematika pada siswa kelas VII SMP Negeri 9 Kota Bima, hal ini dapat di lihat dari skor aktivitas siklus I adalah 3,49 yang berkategori aktif dengan rata-tara nilai 75,18 dan peresentase ketuntasan belajar siswa adalah 76,4\%; 2) pendekatan Open Ended memberikan kontribusi pada peningkatan aktivitas pembelajaran matematika pada siswa kelas VII SMP Negeri 9 Kota Bima, hal ini dapat di lihat dari skor aktivitas siklus II adalah 3,87 yang berkategori aktif dengan rata-rata nilai 83,26 dan peresentase ketuntasan belajar siswa $90 \%$.

\section{REKOMENDASI}

Berdasarkan beberapa temuan penelitian dan simpulan di atas, maka penulis memberikan rekomendasi kepada peneliti berikutnya bahwa perlu dilakukan penelitian lebih lanjut tentang bagaimana pelaksanaan dan upaya-upaya yang dapat dilakukan untuk meningkatkan hasil belajar siswa dengan pendekatan Open Ended pada materi lainnya.

\section{UCAPAN TERIMAKASIH}

Penulis menyampaikan ucapan terima kasih yang sebesar-besarnya kepada Kepala SMP Negeri 9 Kota Bima yang telah mengizinkan penulis untuk mengadakan penelitian dan semua pihak yang telah membantu dalam penyelesaian penelitian ini baik secara langsung maupun tidak langsung.

\section{REFERENSI}

Djamarah, S.B.2002. Psikologi Belajar. Jakarta: Rineka Cipta.

Kusumah, W \& Dwitagama, D. 2010. Mengenal Penelitian Tindakan Kelas. Jakarta: PT Indeks.

Fitriani, A. 2015. Pengaruh Pendekatan Open-Ended Terhadap Kemampuan Berpikir Kreatif Peserta Didik Berbantu Video Interaktif Materi Lingkaran Kelas VIII MTsN 
Mranggen Demak Tahun Ajaran 2014/2015. Skripsi. Semarang: Fakultas Ilmu Tarbiyah dan Keguruan. Universitas Islam Negeri Walisongo.

Mikrayanti, M. (2019). UPAYA MENINGKATKAN HASIL BELAJAR SISWA SEKOLAH MENENGAH PERTAMA MELALUI PENDEKATAN OPEN ENDED. SUPERMAT (JURNAL PENDIDIKAN MATEMATIKA), 3(1), 43-50.

Mulyadin, E. (2019, November). Developing of teaching materials for junior high school students based on ethnomathematics on traditional woven cloth (Tembe Nggoli) of Mbojo tribe. In Journal of Physics: Conference Series (Vol. 1280, No. 4, p. 042044). IOP Publishing.

Rusman. 2012. Model-model Pembelajaran Mengembangkan profesionalisme Guru. Bandung: Rajagrafindo Persada.

Slameto. 2003. Belajar dan Fakto-Faktor Yang Mempengaruhinya. Jakarta: Rineka Cipta.

Sowanto, S. (2018). BAHAN AJAR PADA MATERI GARIS SINGGUNG LINGKARAN DENGAN PENDEKATAN SAINTIFIK UNTUK SISWA SMP. Kalamatika: Jurnal Pendidikan Matematika, 3(1), 63-80.

Suherman, E. Dkk. 2011. Strategi Pembelajaran Matematika Kontemporer. Bandung. UPI.

Suprijono, A. 2009. Cooperative Learning Teori dan Aplikasi Paikem. Yogyakarta: Pustaka Pelajar.

Tianto. 2007. Model-model Pembelajaran Inovatif Berorientasi Konstruktivistik. Jakarta: Prestasi Pustaka.

Trianto. 2011. Model Pembelajaran Terpadu Konsep, Strategi dan Implementasi dalam KTSP. Jakarta: Bumi Aksara

Zainul, A. dan Mulyana, A. 2003. Tes Dan Asesmen Di SD. Jakarta: Universitas Terbuka. 